The Freudian Reading 



\section{The Freudian Reading}

\section{Analytical and Fictional Constructions}

Lis Møller

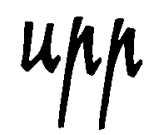

UNIVERSITY OF PENNSYLVANIA PRESS
Philadelphia 
Copyright (C) 1991 by the University of Pennsylvania Press

All rights reserved

Printed in the United States of America

Permission to reprint published material is acknowledged:

From The Standard Edition of the Complete Psychological Works of Sigmund Freud, translated and edited by James Strachey in collaboration with Anna Freud, and assisted by Alix Strachey and Alan Tyson. Copyright (C) 1953-1974 by Sigmund Freud Copyrights, the Institute of Psycho-Analysis, and Hogarth Press. Reprinted by permission of Random Century Group (world rights); selected essays are reprinted with permission of Basic Books, Inc., and Unwin Hyman (U.S. rights).

From Narrative Truth and Historical Truth: Meaning and Interpretation in Psychoanalysis, by Donald P. Spence. New York and London: W.W. Norton and Company, 1982.

Copyright (C) 1982 by Donald P. Spence. Reprinted by permission of Donald P.

Spence.

Library of Congress Cataloging-in-Publication Data

Møller, Lis.

The Freudian reading: analytical and fictional constructions / Lis Møller. p. $\mathrm{cm}$.

Includes bibliographical references and index.

ISBN 0-8122-3126-0 (cloth). - ISBN 0-8122-1381-5 (paper)

1. Freud, Sigmund, 1856-1939. 2. Psychological literature.

3. Psychoanalysis and literature. 4. Hermeneutics-History-20th century. I. Title. BF109.F74M65 1991

$150.19^{\prime} 52-\mathrm{dc} 20$ 
To the memory of

Anne Marie Rahbzek Møller 
